\title{
MUTANTS OF BARLEY HEAT-SENSITIVE FOR CHLOROPLAST DEVELOPMENT
}

by

\author{
ROBERT M. SMILLIE', KNUD W. HENNINGSEN², \\ JOAN M. BAIN ${ }^{1}$, CHRISTA CRITCHLEY ${ }^{1}$, TORSTEN FESTER ${ }^{3}$ \\ and DITER von WETTSTEIN ${ }^{3}$ \\ 'Plant Physiology Unit, CSIRO Division of Food \\ Research and School of Biological Sciences, Macquarie University, \\ P.O. Box 52, North Ryde 2113, Sydney, Australia \\ 2Department of Genetics, The Royal Veterinary and \\ Agricultural University, DK-1870 Copenhagen \\ ${ }^{3}$ Department of Physiology, Carlsberg Laboratory \\ Gamle Carlsberg Vej 10, DK-2500 Copenhagen Valby
}

Keywords: Temperature sensitive mutants, conditional lethals, chloroplast membranes, plastids

\begin{abstract}
Six nuclear gene mutants of barley, heat-sensitive for chloroplast development, are described. These conditional lethal mutants in six different genes can be grown as homozygous viable plants in the field, their mutant phenotype only being expressed with development at high temperature. Chlorophyll accumulation in the mutants but not in the wild type is inhibited by a growth temperature of $31^{\circ} \mathrm{C}$. The degree of temperature sensitivity varies amongst the mutants. For example, partial inhibition of chlorophyll production is evident in the mutant vir-z $f^{\text {ts }} 4$ above $20^{\circ}$ while inhibition is complete at a growth temperature of $29^{\circ}$. The mutant vir-zi ts49 remains green at $29^{\circ}$ but is bleached at $31^{\circ}$. The reduction in chlorophyll content of the leaves at high growth temperatures is accompanied by the appearances of structural abnormalities in the chloroplasts and reduced photochemical activity per mg chlorophyll. The inhibitory effect of elevated temperatures is confined to some early stage of plastid development as the light-dependent conversion of etioplasts into chloroplasts in the mutants is not inhibited at $32^{\circ}$. Leaf elongation in the mutants compared with the wild type is not affected by high growth temperatures. When the mutants are grown at temperatures permitting normal chlorophyll accumulation, the chloroplast thylakoid membranes appear to be no less heat stable than in the wild type.
\end{abstract}




\section{INTRODUCTION}

Higher plants frequently become chlorotic following exposure to temperatures, either hot $(4,17)$ or cold $(2,9,15,17)$, which are on the verge of being injurious to growth of the plants. Barley seedlings become chlorotic at growth temperatures in excess of $32^{\circ} \mathrm{C}(5,17)$.

This phenomenon in barley and in rye results in plants deficient in chlorophyll (5) and chloroplast thylakoid membranes (13), chloroplast ribosomes $(5,13)$ and ribulose-1,5-bisphosphate carboxylase $(5,6)$. Several enzymes of the photosynthetic $\mathrm{CO}_{2}$ fixation cycle (6) and the small subunit of ribulose-1,5-bisphosphate carboxylase (3), which is made on cytoplasmic ribosomes, continue to be synthesized. Thus the high temperature effect appears to be a specific inhibition of chloroplast-localized protein synthetic systems. As such it provides an experimental system for studying chloroplast-cytoplasmic interactions involved in the synthesis of chloroplast proteins (3), as well as the differential control of plant metabolism by temperature.

The power of this experimental system would be enhanced by the availability of mutants in which the minimum growth temperature needed to produce the chloroplast deficiencies has been altered. Such temperature sensitive, conditional lethal mutants in higher plants would furthermore provide selection mechanisms for somatic cell hybrids produced by protoplast fusion in an analogous manner to the light sensitive mutants previously employed for this purpose $(10,11)$. In this paper we describe six barley mutants, heat-sensitive for chloroplast development at temperatures lower than those producing chlorosis in the wild type. The mutants are the result of mutations in six different nuclear genes.

\section{MATERIALS AND METHODS}

\subsection{Screening for heat sensitive mutants}

Resting kernels of Svalöv's Bonus barley were mutagenized in 1969 with ethyleneimine or with $\gamma$-rays from a ${ }^{137} \mathrm{Cs}$ source and the $M_{1}$ generation grown in the experimental fields of the Swedish Seed Association at Svalöv and of the Agricultural Research Department of the Danish Atomic Energy Commission's Research Establishment at Ris $\varnothing$. The $M_{2}$ spikes were planted at Ris $\varnothing$ in a temperature controlled greenhouse with artificial lighting. The air temperature was set at $35^{\circ} \mathrm{C}$ and continuous illumination supplied. As soon as the chlorophyll mutants had reached a primary leaf height of 5 $\mathrm{cm}$, albina, xantha and viridis seedlings were transferred to a constant temperature room kept at $15^{\circ} \mathrm{C}$ and with continuous illumination. Seedlings which greened and survived were grown to maturity and progeny tested. Of the 57 mutants isolated, 9 proved in the progeny tests to have wild type phenotype if grown at $15^{\circ} \mathrm{C}$ and mutant phenotype if grown above $30^{\circ} \mathrm{C}$. Six mutants have been kept as homozygous stocks in the Copenhagen collection since 1970 . For genetic analysis they have been crossed with each other and with all xantha and viridis mutants of the collection (19).

They are designated viridis-yts2, viridis-zf $\mathrm{ts} 4$, viridis-zg $^{\mathrm{ts} 9}$, viridis-z $h^{\mathrm{ts} 46}$, viridis-zi ${ }^{\mathrm{t}} 4 \mathrm{9}$ and viri-

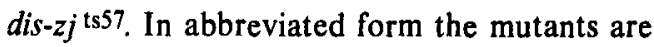
referred to as ts2, ts4, ts9, ts 46 , ts 49 and ts 57. Mutants ts2 and ts9 were induced by a treatment of Bonus grains with a solution of $0.014 \%$ $(\mathrm{v} / \mathrm{v})$ ethyleneimine $(\mathrm{pH} 7.7)$ for 5 hours, whereas mutants ts 4 and ts 49 were isolated after a treatment with a concentration of $0.030 \%$ ethyleneimine. Mutants ts 46 and ts 57 originated in an $\mathbf{M}_{2}$ material from grains treated with an acute dose of $12,000 \mathrm{rad} \gamma$-rays.

\subsection{Growth conditions}

Wild-type barley (Hordeum vulgare L. cv. Svalöv's Bonus) and the six mutants were grown in a growth chamber or where growth at several temperatures was to be compared, in glass tubes in water baths as described previously (17). In this second method seeds were germinated for 28 hours in running tap water before being planted in vermiculite contained in glass tubes $(4 \mathrm{~cm}$ dia. $\times 30 \mathrm{~cm}$ ). The tubes

Abbreviations: $\mathrm{DCIP}=2,6$ dichlorophenol indophenol; $\mathrm{DCMU}=3-\left(3^{\prime}, 4^{\prime}\right.$ dichlorophenyl)-1,1-dimethylurea. 
were placed in water baths $\left( \pm 0.1^{\circ} \mathrm{C}\right)$ for the times indicated in the text. Continuous overhead illumination of 4500 lux at seed level was provided by white fluorescent lights.

\subsection{Absorption and fluorescence measurements}

Absorption spectra or fluorescence measurements were made on the area of the primary leaf 3 to $4 \mathrm{~cm}$ below the leaf tip. An Aminco DW-2 spectrophotometer in the split-beam mode was used to record the absorption spectra. The same spectrophotometer equipped with a total fluorescence accessory was used for recording the heat-induced rise in chlorophyll fluorescense (16). The temperature of the leaf section was increased by water circulated from a water bath and heater at a rate of $1^{\circ} \mathrm{C}$ per minute.

\subsection{Chloroplast isolation and assays}

Chloroplast thylakoids were isolated from primary leaves (less the first one $\mathrm{cm}$ of the tip) as previously described (12).

Chloroplast activities were assayed at $23^{\circ} \mathrm{C}$ using an Aminco DW-2 spectrophotometer operated in the dual-wavelength mode. Photoreduction of ferricyanide was measured at 420 $\mathrm{nm}$ minus $450 \mathrm{~nm}$ in a reaction mixture $(1.5 \mathrm{ml})$ consisting of chloroplast thylakoids $(4 \mu \mathrm{g}$ chlorophyll. $\left.\mathrm{m}^{-1}\right), 0.05 \mathrm{M}$-Sørensen's phosphate buffer ( $\mathrm{pH} 7.5), 0.05 \mathrm{M}-\mathrm{NaCl}, 0.05 \%(\mathrm{w} / \mathrm{v})$ bovine serum albumin, and $0.34 \mathrm{mM} \mathrm{K}_{3} \mathrm{Fe}(\mathrm{CN})_{6}$. Red actinic light (11. $10^{4}$ ergs $\left.\mathrm{cm}^{-2} \cdot \mathrm{sec}^{-1}\right)$ was provided by light from a $150 \mathrm{~W}$ tungsten lamp filtered through heat filters (Calflex $\mathrm{C}$ and Corning 1-75) and a Corning 2-60 red cut-off filter. Photoreduction of NADP using reduced DCIP as the electron donor (photosystem 1 activity) was measured at $350 \mathrm{~nm}$ minus $370 \mathrm{~nm}$ using a reaction mixture $(1.5 \mathrm{ml})$ containing

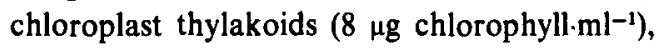
0.03 M-Sørensen's phosphate buffer ( $\mathrm{pH} 7.5$ ), $0.03 \mathrm{M}-\mathrm{NaCl}, 0.03 \%(\mathrm{w} / \mathrm{v})$ bovine serum albumin, $0.67 \mathrm{~mm}$-NADP, $2.5 \mathrm{~mm}$-ascorbate, 63 $\mu \mathrm{M}$-DCIP, $1.4 \mu \mathrm{M}$-ferredoxin from Anacystis nidulans, 6.7 $\mu \mathrm{M}$-DCMU and gramicidin D (4 $\left.\mu \mathrm{g} \cdot \mathrm{ml}^{-1}\right)$. The intensity of red actinic light was 3 $\times 10^{4} \mathrm{ergs} \mathrm{cm}^{-2} \cdot \mathrm{sec}^{-1}$. Chlorophyll concentra- tions in leaves and chloroplast suspensions were determined (1) after extraction with $80 \%(v / v)$ acetone.

\subsection{Electron microscopy}

The primary leaf tissue was cut between 3 to $4 \mathrm{~cm}$ below the tip into pieces $3 \mathrm{~mm} \times 0.5 \mathrm{~mm}$ and fixed at $20^{\circ} \mathrm{C}$ in formaldehyde-glutaraldehyde (8) containing 7\% sucrose. After washing in $0.1 \mathrm{M}$-phosphate buffer $\mathrm{pH} 7.2$ containing $7 \%$ sucrose, the tissue was post-fixed for $2 \mathrm{hr}$ in $1 \% \mathrm{OsO}_{4}$, stained in $2 \%$ aqueous uranyl acetate for $30 \mathrm{~min}$, washed and dehydrated through a graded series of alcohol and embedded in Spurr's resin. Thin sections were stained with $2 \%$ uranyl acetate and with lead citrate and examined in a Siemens Elmiskop I electron microscope.

\section{RESULTS AND DISCUSSION}

\subsection{Genetic analyses of the mutants}

When tested under restrictive temperature conditions, the six mutants behaved in crosses as recessive nuclear gene mutants. All pairwise combinations of the six mutants yielded $F_{1}$ seedlings with wild-type phenotype showing them to be mutations in six different genes. Allele tests of five of the mutants with the 32 previously identified viridis genes and the 20 previously identified xantha genes (19) as well as with 23 other loci giving rise to seedling lethals revealed no allelism with any of these loci. The five mutants are therefore given the gene designations vir-zf ts4 $^{2}$ vir-zg ts9, vir-zh $h^{\text {ts } 46}$, $v i r-z i{ }^{\text {ts } 49}$ and $v i r-z j{ }^{\text {ts57. The sixth mutant } v i r-y}$ ts 2 was found to be allelic to the recessive lethal viridis- $y^{59}(7)$. The $F_{1}$ of the cross $+/ y^{59} \times t^{2} / s^{2}$ grown at $35^{\circ} \mathrm{C}$ segregated 47 green to 33 white seedlings, i.e. approximately in a $1: 1$ ratio. In the gene viridis-y there is thus available now a lethal and a conditional lethal allele. The mutant viridis-ys $y^{39}$ white with a green tinge and frequently with a green tip when grown at temperatures ranging from $2^{\circ}$ to $31^{\circ} \mathrm{C}$. It has previously been shown (7) to contain very little chlorophyll and to accumulate photoconvertible protochlorophyllide and some protopor- 
Table I

Chlorophyll accumulation in ts-mutants grown at $21^{\circ} \mathrm{C}$ and $32^{\circ} \mathrm{C}$

\begin{tabular}{lcccc}
\hline Mutant & \multicolumn{5}{c}{ Growth temperature } \\
\cline { 2 - 5 } & \multicolumn{2}{c}{$21^{\circ} \mathrm{C}$} & & \multicolumn{2}{c}{$32^{\circ} \mathrm{C}$} & \\
\cline { 2 - 5 } & $\begin{array}{l}\text { Total chlorophyll } \\
\mu \mathrm{g}(\mathrm{g} \text { fresh wt) }\end{array}$ & Chlorophyll $a / b$ & $\begin{array}{c}\text { Total chlorophyll } \\
\mu \mathrm{g}(\mathrm{g} \text { fresh wt) }\end{array}$ & Chlorophyll $a / b$ \\
\hline ts2 & 1390 & 3.6 & 390 & \\
ts4 & 1620 & 3.6 & 230 & 2.7 \\
ts9 & 1560 & 4.4 & 580 & 2.7 \\
ts46 & 1240 & 3.9 & 250 & 2.8 \\
ts49 & 1530 & 3.6 & 380 & 3.2 \\
ts57 & 1140 & 3.4 & 290 & 2.3 \\
\hline
\end{tabular}

Seedlings were grown in growth cabinets at $21^{\circ} \mathrm{C} \pm 0.5^{\circ} \mathrm{C}$ under continuous white light ( 1700 lux) for 8 days or at $32^{\circ} \mathrm{C} \pm 0.5^{\circ} \mathrm{C}$ also under continuous white light (2400 lux) for 7 days. Analyses were carried out on the top $15-\mathrm{cm}$ segment og the primary leaf.

phyrin IX upon feeding with $\delta$-aminolevulinate. As expected from its low chlorophyll content, oxygen evolution could not be detected with the mutant.

\subsection{Chlorophyll inhibition in ts-mutants at $32^{\circ} \mathrm{C}$}

Growth of the ts-mutants at $32^{\circ} \mathrm{C}$ resulted in inhibition of chlorophyll production. In Table I, chlorophyll production is compared in mutants grown at $21^{\circ} \mathrm{C}$ and $32^{\circ} \mathrm{C}$. In mutants grown at the higher temperature, chlorophyll production was confined to the tip of the primary leaf. These green areas had lower ratios of chlorophyll $a$ to $b$ than plants grown at $21^{\circ} \mathrm{C}$, but were capable of oxygen evolution in the light as determined using a platinum electrode. Chlorophyll accumulation is not inhibited in wildtype barley grown at $32^{\circ} \mathrm{C}(17$, see also below).

\section{Table II}

Greening of ts-mutants

\begin{tabular}{|c|c|c|c|c|c|c|c|c|}
\hline \multirow{4}{*}{ Mutant } & \multicolumn{8}{|c|}{ Growth conditions } \\
\hline & \multicolumn{2}{|c|}{$\begin{array}{c}\text { Dark, } 6 \text { days: } \\
23^{\circ} \mathrm{C}\end{array}$} & & & \multicolumn{2}{|c|}{$32^{\circ} \mathrm{C}$} & & \\
\hline & \multicolumn{2}{|c|}{$\begin{array}{c}+ \text { Light, } 24 \mathrm{hr}: \\
21^{\circ} \mathrm{C}\end{array}$} & \multicolumn{2}{|c|}{$32^{\circ} \mathrm{C}$} & \multicolumn{2}{|c|}{$21^{\circ} \mathrm{C}$} & \multicolumn{2}{|c|}{$32^{\circ} \mathrm{C}$} \\
\hline & $\mathrm{Ch}^{1)}$ & $\left.a / b^{2}\right)$ & Chl & $a / b$ & $\mathrm{Chl}$ & $a / b$ & $\mathrm{Chl}$ & $a / b$ \\
\hline $\mathrm{ts} 2$ & 1010 & 3.2 & 1190 & 3.1 & 160 & 27 & 260 & 5.8 \\
\hline ts 4 & 1140 & 3.2 & 1510 & 2.9 & 68 & 30 & 220 & 11.2 \\
\hline ts 9 & 1010 & 3.0 & 1870 & 2.7 & 68 & 30 & 170 & 12.4 \\
\hline ts 46 & 1280 & 3.0 & 1760 & 3.1 & 97 & 330 & 300 & 5.8 \\
\hline ts 49 & 1300 & 3.0 & 1850 & 3.0 & 66 & 30 & 230 & 5.9 \\
\hline ts 57 & 980 & 2.8 & 1590 & 3.1 & 96 & 30 & 270 & 5.4 \\
\hline
\end{tabular}

The mutants were grown in the dark at $23 \pm 0.5^{\circ} \mathrm{C}$ or $32 \pm 0.5^{\circ} \mathrm{C}$ and then illuminated with light $(\sim 3000$ lux $)$ at the temperatures shown.

1) $\mu \mathrm{g}$ chlorophyll $(a+b)$ per $\mathrm{g}$ fresh weight primary leaf

2) ratio of chlorophyll $a$ to chlorophyll $b$ 


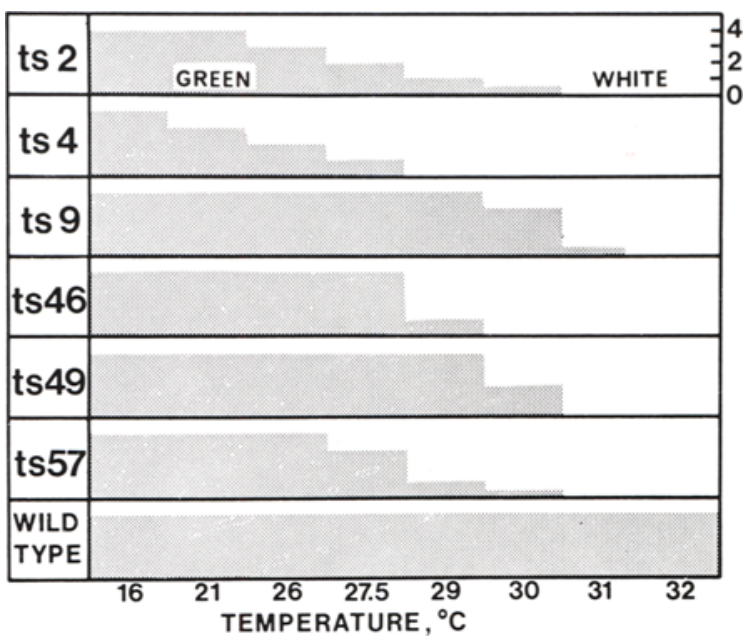

Figure 1a: Visual grading for chlorophyll in tsmutants grown at different temperatures for 7 days. Grading was based on a scale of $O$ (white) to 4 (wild type grown at $26^{\circ} \mathrm{C}$ ) for the primary leaf (excluding the first $1 \mathrm{~cm}$ of the tip). Leaves showing a trace of chlorophyll were given a grading of 0.5 .

\subsection{Greening of the ts-mutants}

The inhibitory effect of high temperature on chlorophyll accumulation shown in Table I could result either from inhibition of the lightdependent conversion of the etioplast into a chloroplast or from inhibition at some earlier developmental stage. It was possible to distinguish between these two possibilities by growing the mutants in the dark at either $23^{\circ} \mathrm{C}$ or $32^{\circ} \mathrm{C}$, and then illuminating them and measuring chlorophyll production. The results are shown in Table II. Mutants grown in the dark at $23^{\circ} \mathrm{C}$ turned green when illuminated at either $21^{\circ} \mathrm{C}$ or $32^{\circ} \mathrm{C}$. Thus a temperature of $32^{\circ} \mathrm{C}$ did not inhibit the conversion of etioplasts to chloroplasts. In contrast, chlorophyll synthesis was inhibited in mutants grown at $32^{\circ} \mathrm{C}$ in the dark, irrespective of the greening temperature. None of the growth conditions listed in Table II inhibited greening in the wild type.

\subsection{Chlorophyll accumulation at different growth temperatures}

Differential heat sensitivity between the various ts-mutants for chlorophyll production was demonstrated by growing the mutants at a variety of temperatures. Since the degree of temperature control needed for these experiments could not be obtained using the growth cabinets, the mutants were grown in glass cylinders immersed in water baths (see 2.2.). The effect of growth temperature on chlorophyll production was assessed by visual colour grading, extraction of leaf chlorophyll, or by recording the absorption spectrum of the intact leaf. Colour grading was developed as the most convenient and rapid procedure for surveying the effect of growth temperature on chlorophyll accumulation in mutants. Figure 1a shows results obtained with the six ts-mutants and the wild type grown at eight different temperatures and Figure $1 \mathrm{~b}$ gives an impression of the colours for five of the mutants grown at different temperatures. As noted above, the tip of the primary leaf of the mutants was green, at high growth temperatures, presumably because this region contained cells which were formed during kernel development or during the 28-hour period of water imbibition. For this reason the

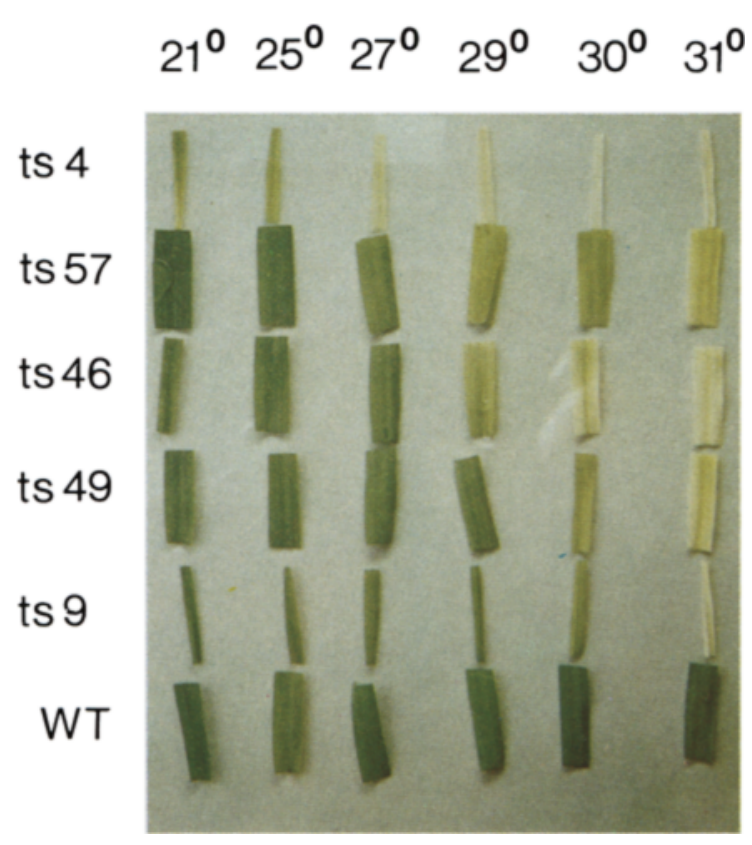

Figure lb: Appearance of leaf segments from five ts mutants and wild type grown at a series of temperatures. The segments of ts 4 and ts 9 are from secondary leaves, those of the others from primary leaves. 


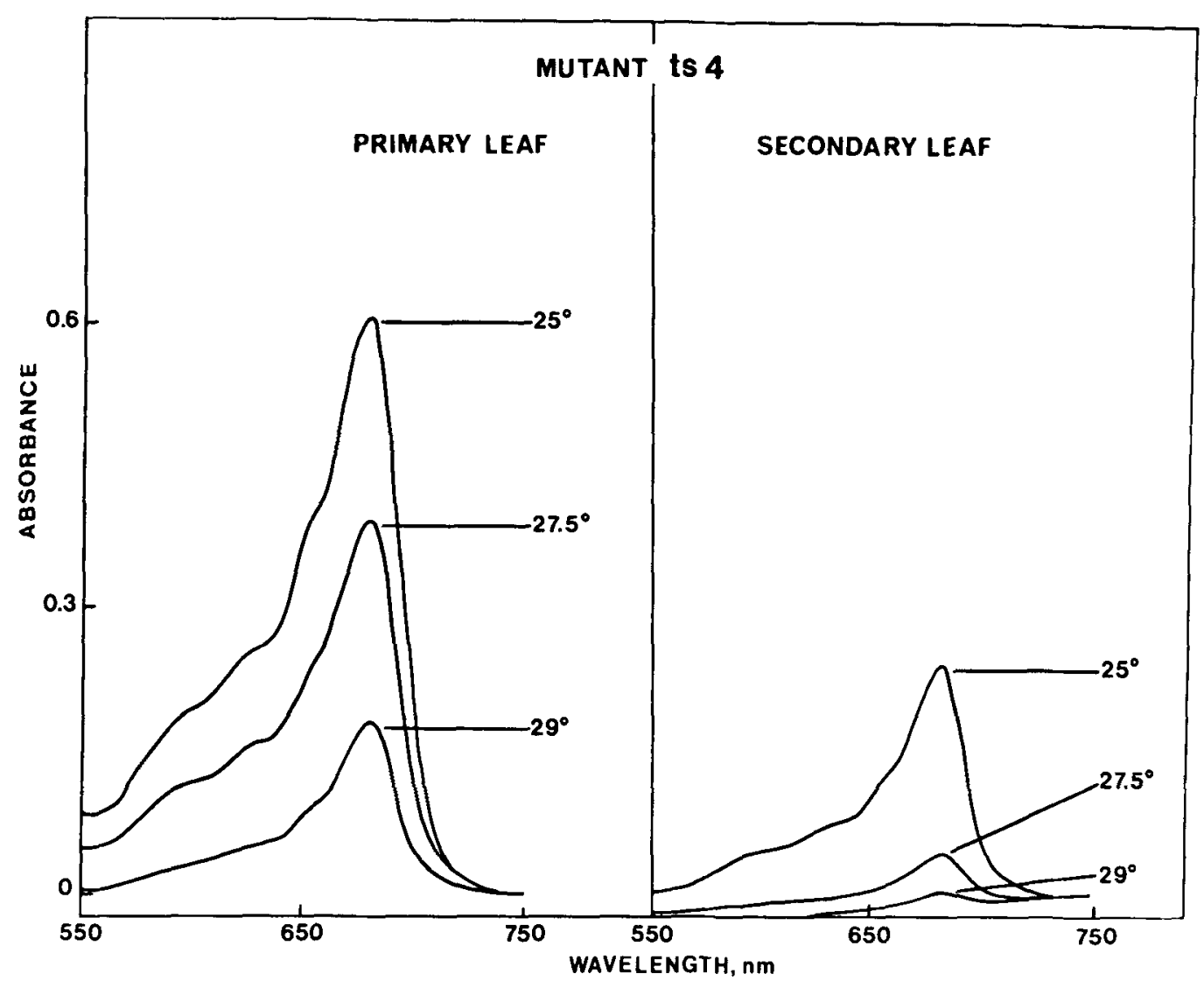

Figure 2: Absorption spectra of the primary and secondary leaves of the mutant ts 4 grown at $25,27.5$ and $29^{\circ} \mathrm{C}$.

first $1 \mathrm{~cm}$-tip of the primary leaf was not used for any of the analyses which follow. Colour variations were not observed among seedlings of a given mutant grown at any one temperature.

The mutants ts 2 , ts 9 , ts 49 and ts 57 appeared white or contained traces of green colour when grown at $31^{\circ} \mathrm{C}$ and were white when grown at $32^{\circ} \mathrm{C}$. The high temperature cut-off for chlorophyll production was sharp in ts9 and ts 49 ; chlorophyll production was almost normal at 28 to $29^{\circ} \mathrm{C}$ but was completely inhibited by raising the temperature a further 2 degrees. The high temperature inhibition was more gradual in ts2, while ts 57 was intermediate between ts 2 and the other two mutans. Except for the green tip of the primary leaf, the colours of the primary and secondary leaves of these mutants were the same.
The most heat sensitive of the mutants were ts 4 and ts46. In both of these mutants and in contrast to the other four, the central vein area of the primary leaf showed higher degrees of heat tolerance for chlorophyll production than the rest of the leaf. Thus in ts 46 the central vein area was pale green at $30^{\circ} \mathrm{C}$ although chlorophyll synthesis in the rest of the leaf was arrested at $29^{\circ} \mathrm{C}$.

The mutant ts 4 also showed a considerable difference in colour gradation between the primary and secondary leaves, chlorophyll production in the latter leaves being even more heat-sensitive (Figure 1b) than was indicated for the primary leaf in Figure 1a. This difference is shown in Figure 2 in which the 'in vivo' absorption spectra of primary and secondary leaves of ts 4 grown at different temperatures are compared. 


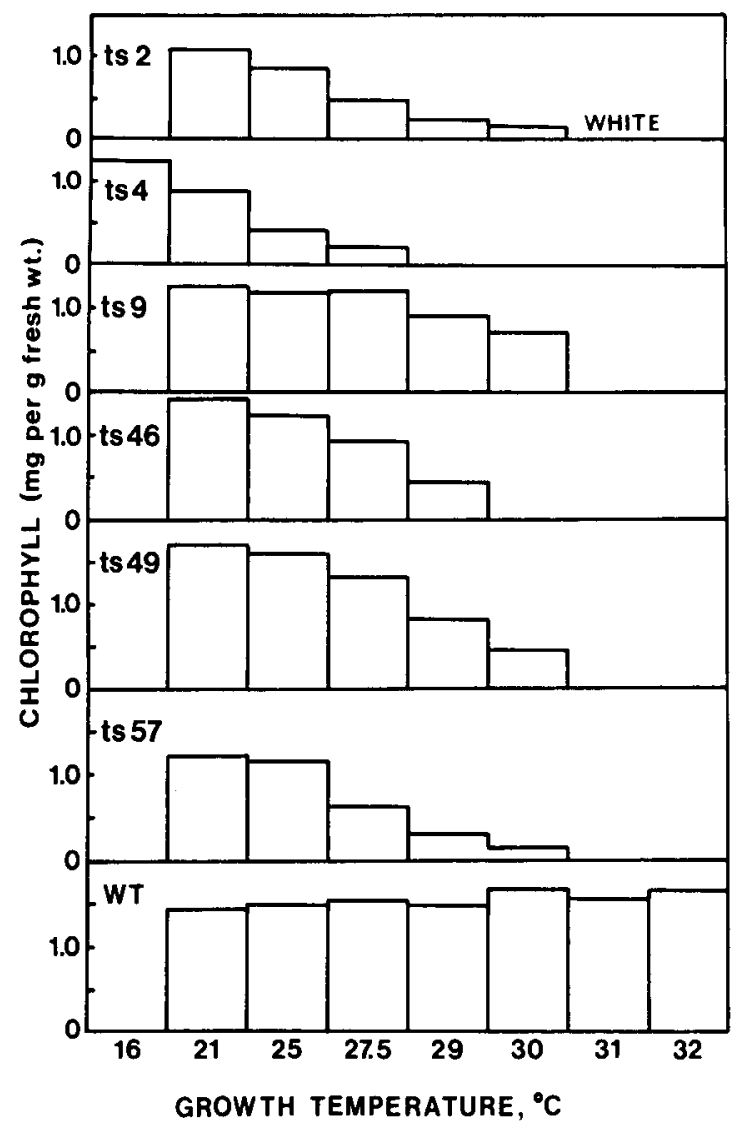

Figure 3: Chlorophyll content of primary leaves of ts-mutants and the wild type grown for 6 days at temperatures from $16^{\circ} \mathrm{C}$ to $32^{\circ} \mathrm{C}$. The first $1 \mathrm{~cm}$ (tip) of each leaf was removed and discarded before the leaves were weighed and extracted for chlorophyll. Measurements were not made on leaves that were white or contained only traces of green.

Figure 3 shows estimations of the chlorophyll content of leaves of the ts-mutants and the wild type grown at different temperatures. The trends obtained are similar to those shown in Figure 1, except that the decreases in chlorophyll with increasing growth temperature are more gradual than it would appear from colour grading. This can be attributed to the difficulty in assessing degrees of colour at chlorophyll concentrations in excess of $50 \%$ of normal. In contrast to chlorophyll production, there were only small differences in growth rates between the mutants and wild type primary leaves (Figure 4). Thus the marked heat sensitivity of chloroplast development in the mutants was not paralleled by a similar effect of high temperature on leaf elongation.

\subsection{Changes in chloroplast structure}

Figure 5 shows the effect of elevated growth temperatures on the structure of chloroplasts in the mutant ts57. Grana were well developed in chloroplasts grown at $26^{\circ} \mathrm{C}$ and $28^{\circ} \mathrm{C}$ (Figures $5 \mathrm{a}$ and $\mathrm{b}$ ) even though the chlorophyll content of the leaves was considerably reduced at the latter temperature (Figure 3). However, at $28^{\circ} \mathrm{C}$ the orientation of the grana was random with respect to each other in the majority of the plastids and the intergrana lamellae were poorly developed. Plants grown at $29^{\circ} \mathrm{C}$ contained a

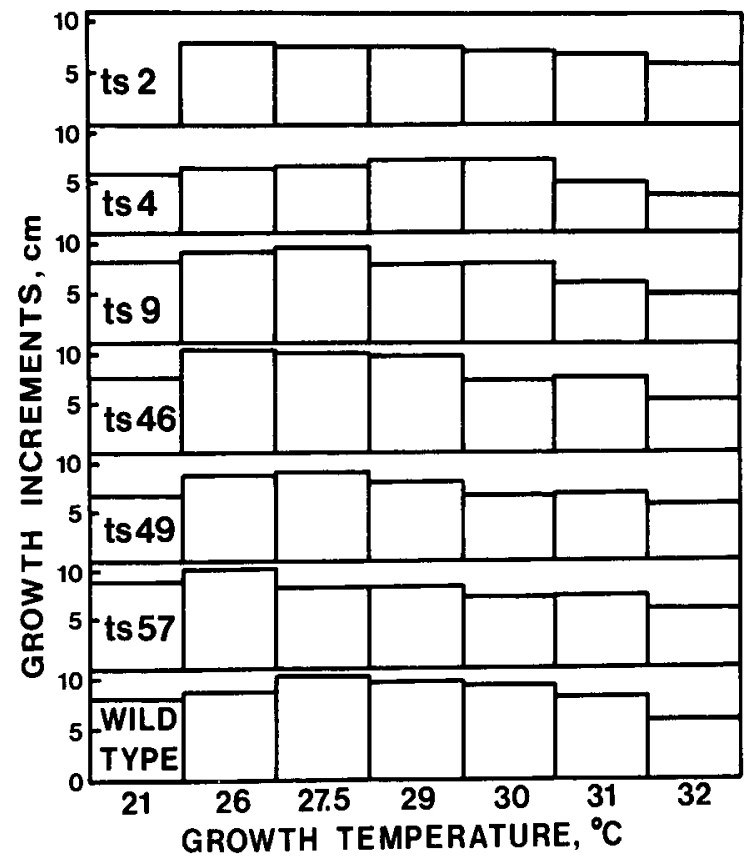

Figure 4: Elongation growth of ts-mutants and the wild type at different temperatures. Values shown are the average increase in height of 10 to 12 plants at each temperature between the 3 rd and 5 th day of growth. 

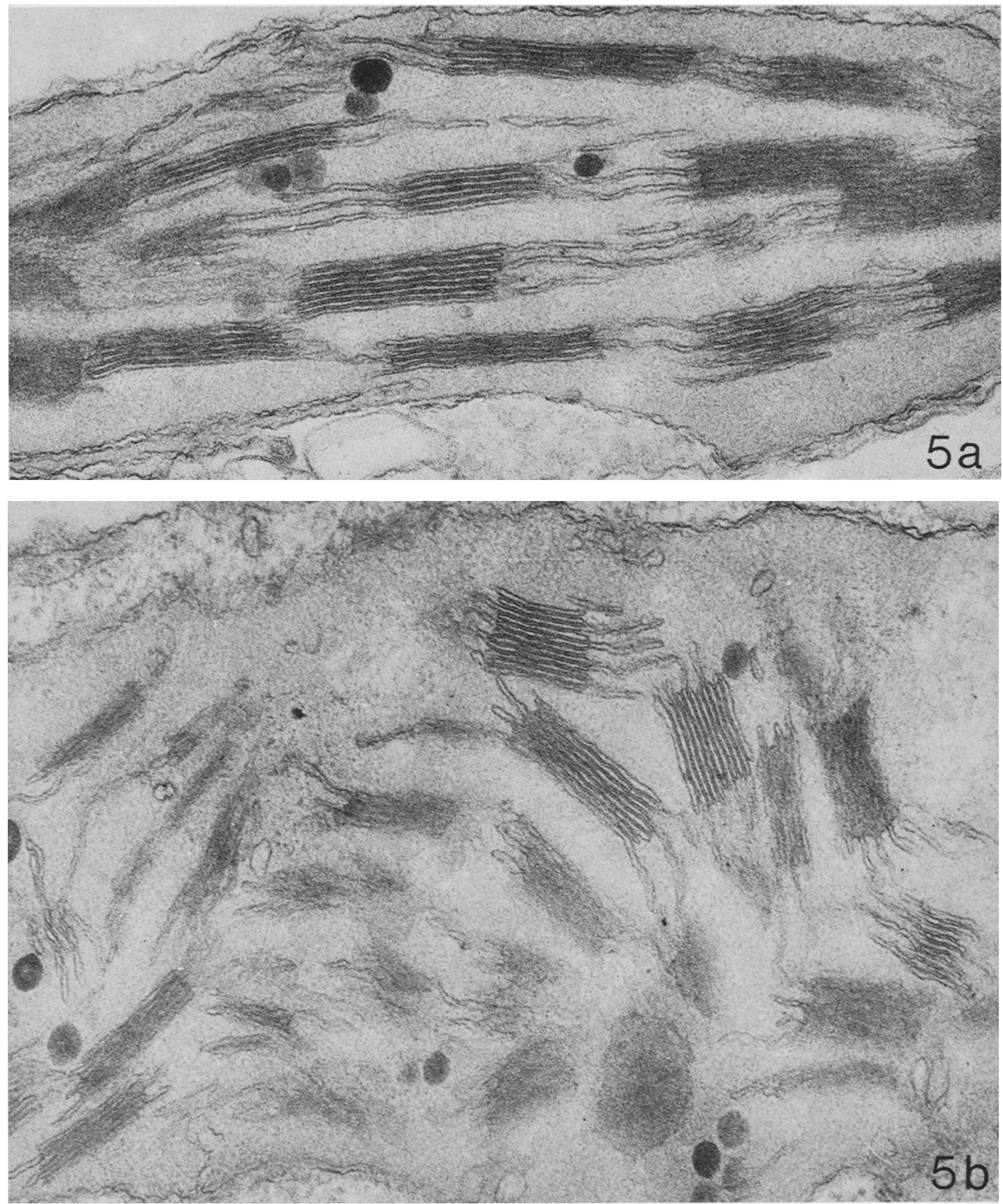

Figure 5: Ultrastructure of the plastids of mutant viridis $-z j{ }^{\mathrm{t} s 57}$.

a) grown at $26^{\circ} \mathrm{C} ; 70,000 \times$

b) grown at $28^{\circ} \mathrm{C} ; 70,000 \times$

c-e) grown at $29^{\circ} \mathrm{C} ; 50,000 \times$

f) grown at $30^{\circ} \mathrm{C} ; 70,000 \mathrm{x}$ 

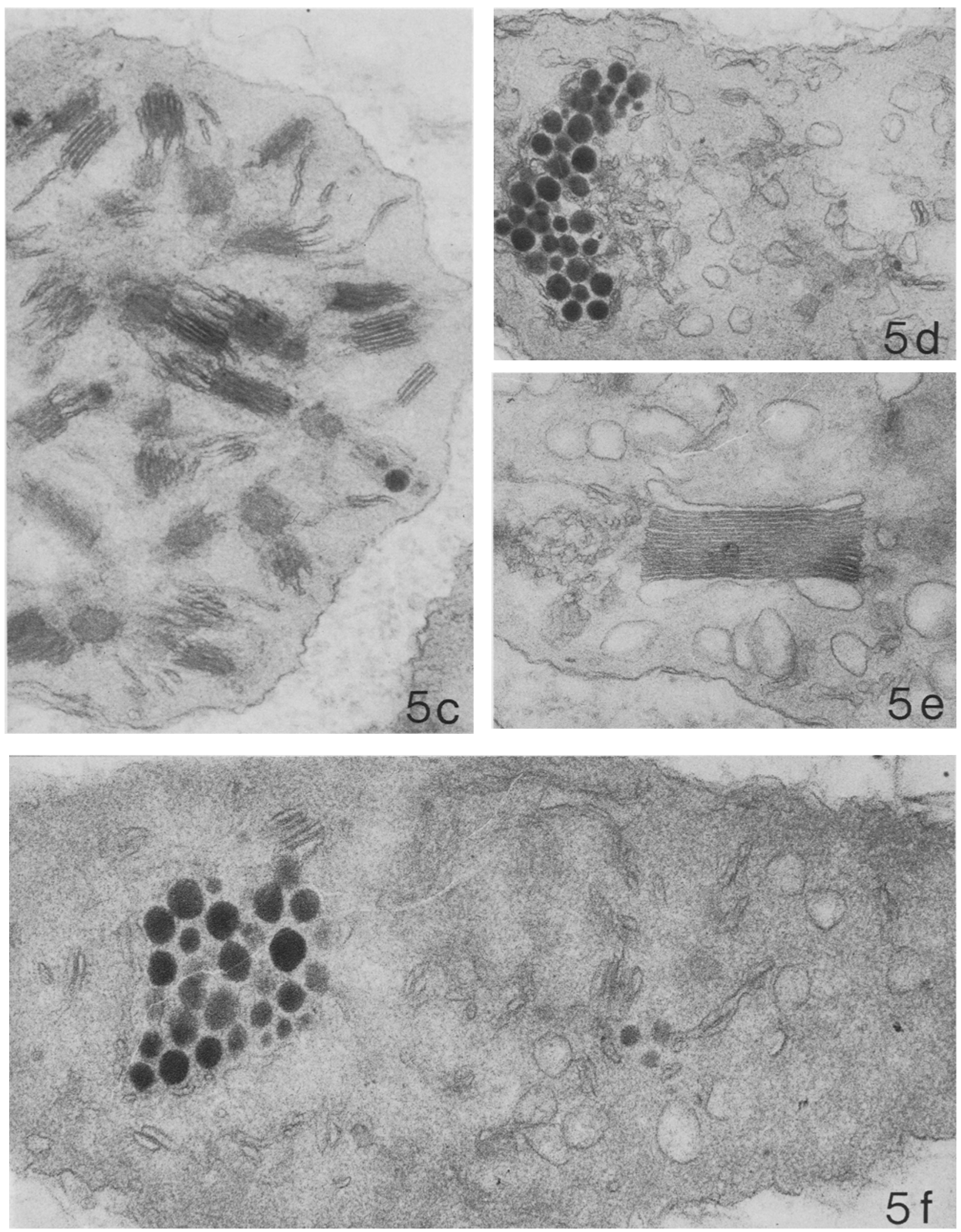


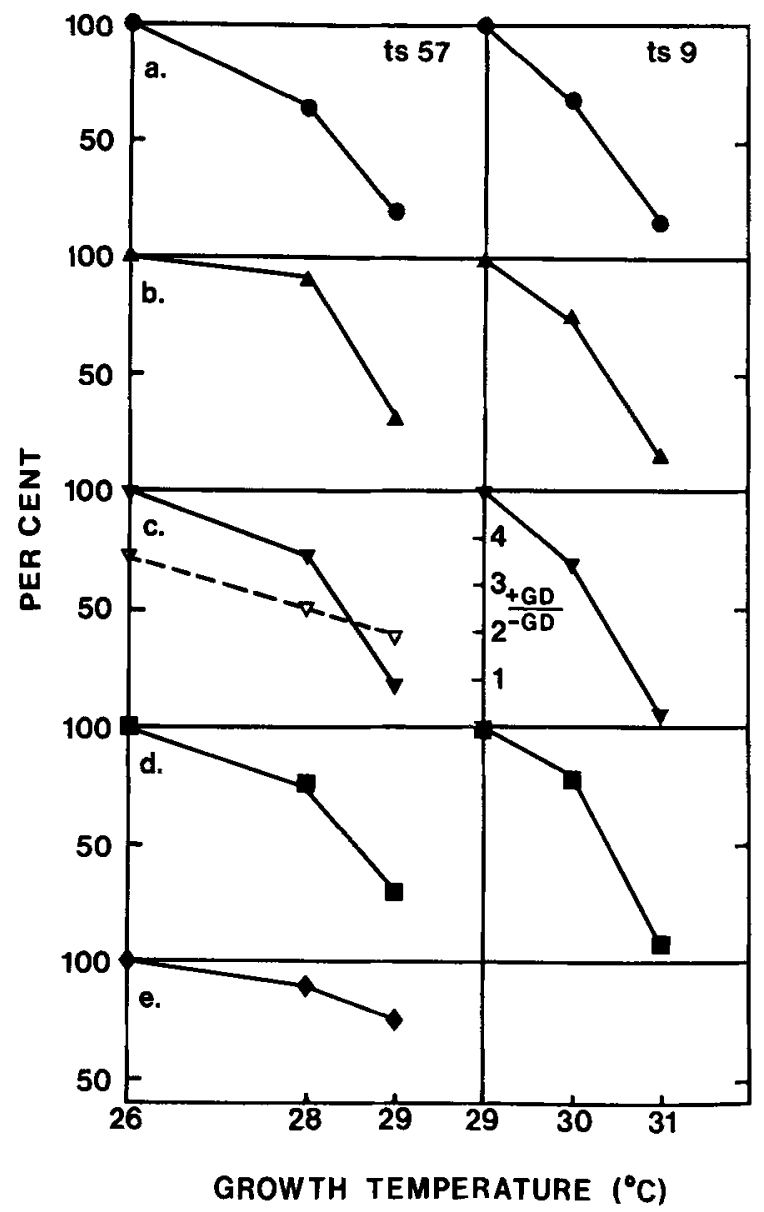

Figure 6: Photochemical activities of chloroplasts isolated from ts57 grown at $26^{\circ}, 28^{\circ}$ and $29^{\circ}$ and ts 9 grown at 29,30 and $31^{\circ} \mathrm{C}$. a, leaf chlorophyll; b, photoreduction of ferricyanide; $c$, photoreduction of ferricyanide in the presence of gramicidin D (4 $\left.\mu \mathrm{g} \cdot \mathrm{ml}^{-1}\right)$. The dashed line in the case of ts57 shows the ratio of activities in the presence and absence of gramicidin D (GD); d, photoreduction of ferricyanide in the presence of $0.1 \mathrm{~mm} p$-phenylenediamine; e, photosystem 1 activity (cf. 2.4). Results are expressed as a percentage of the values obtained at the lowest growth temperature used for each mutant. For ferricyanide photoreduction these were around $300 \mu$ moles reduced (mg chlorophyll) $)^{-1}$ hour ${ }^{-1}$ in the presence of either gramicidin $\mathrm{D}$ or $p$-phenylenediamine.

variety of chloroplasts with different internal organizations. A few plastids contained grana with random orientation (Figure 5c). In most plastids the internal membranes consisted of swollen thylakoids, small grana containing two discs and an occasional abnormally large granum (Figure 5d, e). Clusters of osmiophilic globuli was a common feature. In cells grown at $30^{\circ} \mathrm{C}$ the reduction and disorganization of the internal membranes was enhanced (Figure 5f). Similar structural changes in the chloroplast organization were observed when mutant ts 9 was grown at temperatures from $29^{\circ}-31^{\circ} \mathrm{C}$.

\section{Table III}

The effect of intermittently lowering the growth temperature on chlorophyll production in mutant ts9

\begin{tabular}{lcr}
\hline Growth temperatures & $\begin{array}{c}\text { Av. height of } \\
\text { seedlings }(\mathrm{mm})\end{array}$ & $\begin{array}{c}\text { Chlorophyll content } \\
{\left[\mu \mathrm{g}(\mathrm{g} \text { fresh wt })^{-1}\right]}\end{array}$ \\
\hline $31^{\circ} \mathrm{C}, 1$ hr per day at $28^{\circ} \mathrm{C}$ & 110 & 89 \\
$31^{\circ} \mathrm{C}, 1$ hr per day at $16^{\circ} \mathrm{C}$ & 110 & 139 \\
$31^{\circ} \mathrm{C}, 2.5$ hr per day at $28^{\circ} \mathrm{C}$ & 110 & 119 \\
$31^{\circ} \mathrm{C}, 2.5$ hr per day at $16^{\circ} \mathrm{C}$ & 110 & 101 \\
$31^{\circ} \mathrm{C}, 6$ hr per day at $28^{\circ} \mathrm{C}$ & 120 & 321 \\
$31^{\circ} \mathrm{C}, 6$ hr per day at $16^{\circ} \mathrm{C}$ & 80 & 281 \\
$31^{\circ} \mathrm{C}$, constant & 90 & 48 \\
$28^{\circ} \mathrm{C}$, constant & 119 & 955 \\
$16^{\circ} \mathrm{C}$, constant & 84 & 581
\end{tabular}

Seeds were germinated for 26 hours in running tap water and then transferred to glass containers in water baths maintained at the temperatures given in the table. Analyses were carried out 5 days later. 


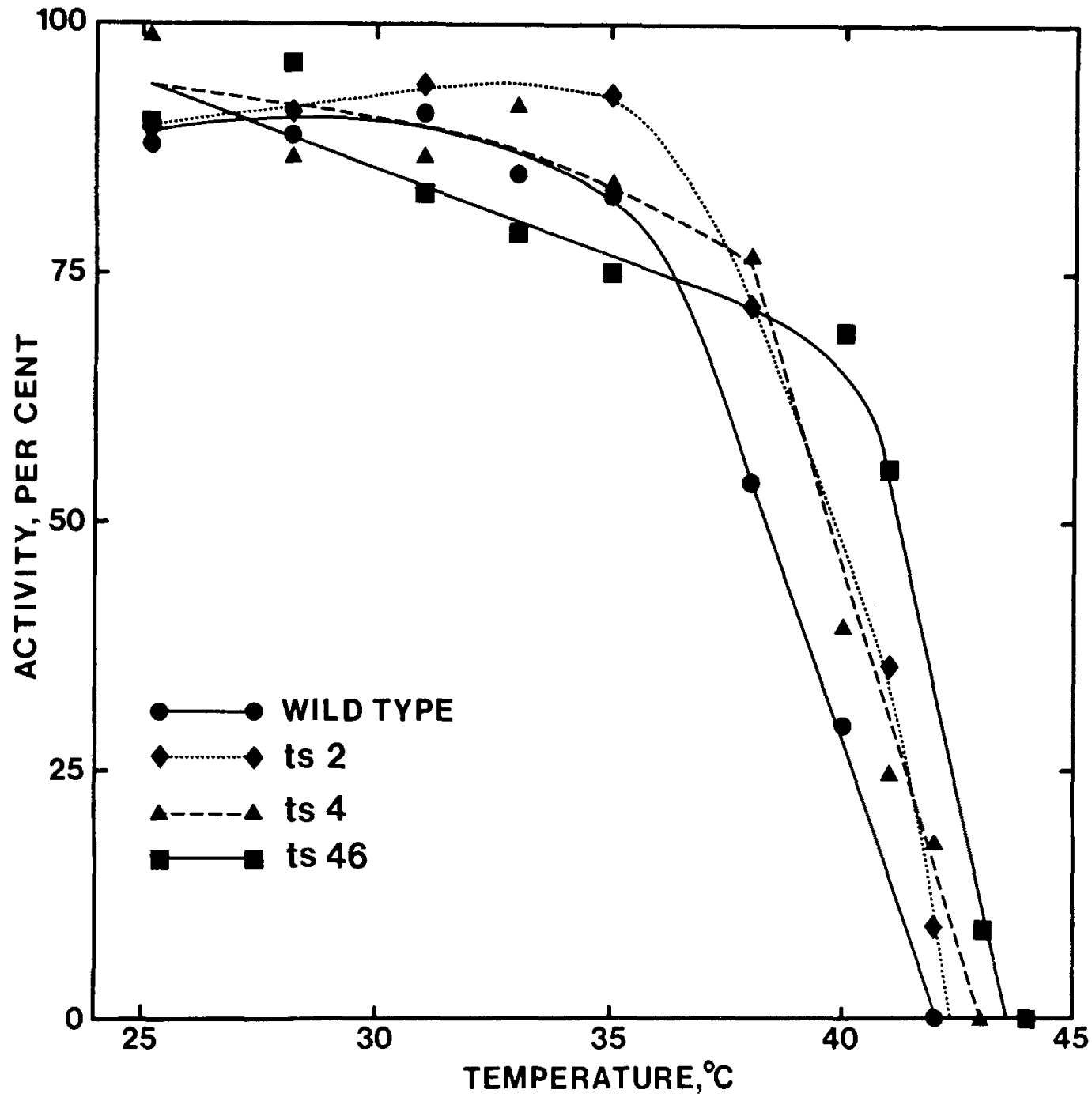

Figure 7: Heat lability of the photoreduction of ferricyanide in chloroplast thylakoids isolated from wild type and the mutants $\mathrm{ts} 2, \mathrm{ts} 4, \mathrm{ts} 46$. The isolated thylakoids were heated to various temperatures and then assayed for photoreduction of ferricyanide at $24^{\circ} \mathrm{C}$ as follows. Aliquots $(20 \mu \mathrm{l})$ of thylakoid suspension $(300 \mathrm{mg}$ chlorophyll. $\mathrm{ml}^{-1}$ ) were added to cuvettes immersed in a water bath with temperatures increasing successively from $25^{\circ} \mathrm{C}$ to $44^{\circ} \mathrm{C}$ (x-axis in the Figure). After $4 \mathrm{~min}$, the cuvette was transferred to a water bath at $24^{\circ} \mathrm{C}$ and reaction mixture $\left(1.5 \mathrm{ml}\right.$ at $\left.24^{\circ} \mathrm{C}\right)$ was added. After a further $2 \mathrm{~min}$ for temperature equilibration, photoreductive activity was assayed at $24^{\circ} \mathrm{C}$. The results are plotted as a percentage of the activity in control samples which were not heated.

\subsection{Changes in chloroplast activity}

Figure 6 compares photochemical activities of chloroplasts isolated from ts 57 to ts9 grown at temperatures producing different degrees of inhibition of chloroplast development. The lowest temperature selected for each mutant allowed chlorophyll to accumulate to $80-100 \%$ of the maximum level. All of the preparations were active in reactions involving photosystems 1 and 2. However, the decrease in leaf chlorophyll (Figure 6a) was accompanied by a decrease in activity per $\mathrm{mg}$ chlorophyll indicating 


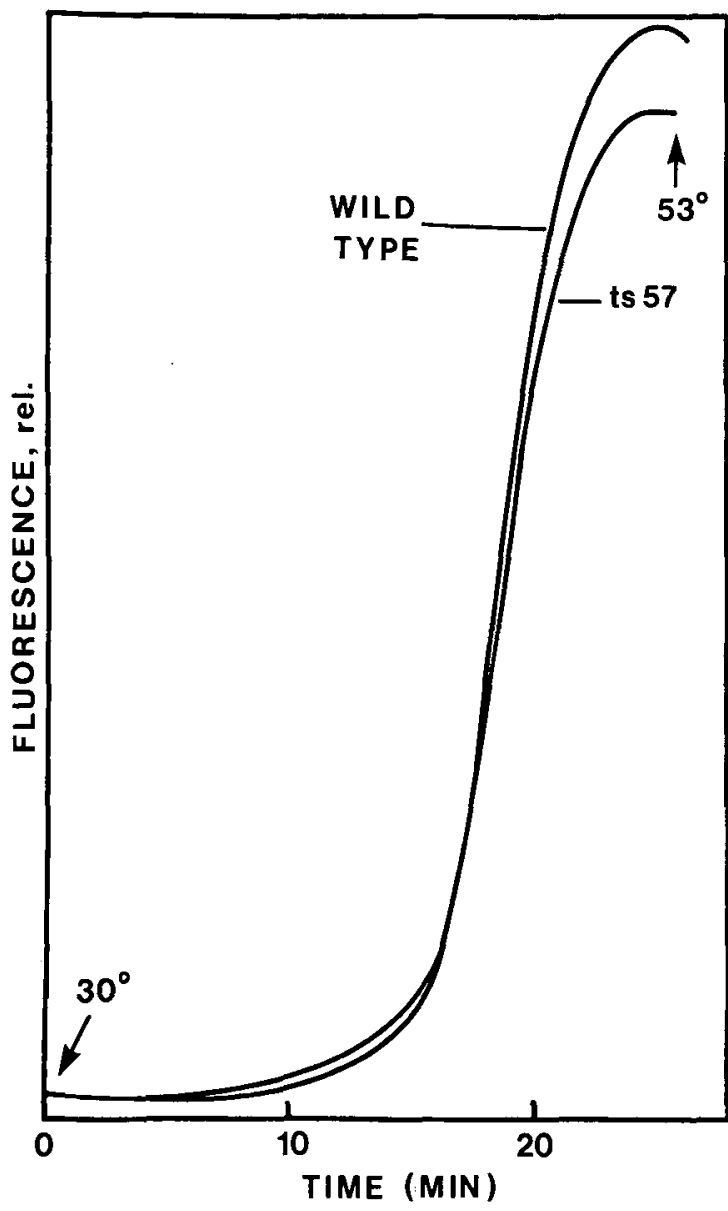

Figure 8: Increase in chlorophyll fluorescence in leaf sections of wild type and ts 57 heated at $1^{\circ} \mathrm{C}$ per minute.

that chloroplasts which developed at high temperatures became more and more functionally incompetent as the growth temperature was raised. Activities of chloroplasts from ts 57 involving both photosystems (Figure $6 \mathrm{~b}, \mathrm{c}$ ) or photosystem 2 alone (Figure 6d) were more heat sensitive than photosystem $\mathrm{l}$ activity (Figure 6e).

\subsection{The effect of intermittently lowered temperatures on heat bleaching}

If high growth temperatures interfere with some regulatory mechanism controlling chloroplast development rather than by a direct in- hibition of synthetic processes, then it might be possible to negate the effect of high temperature by interpolating relatively short periods of exposure to low temperature. This possibility was tested and shown to be unlikely in the mutant ts9. The results are shown in Table III. Decreasing the temperature to either $28^{\circ} \mathrm{C}$ or $16^{\circ} \mathrm{C}$ for 1 hour or 2.5 hours per day had only a slight effect in increasing the chlorophyll content of the leaves compared with control plants grown at a constant $31^{\circ} \mathrm{C}$. Increasing the period of exposure to $28^{\circ} \mathrm{C}$ to 6 hours per day increased the chlorophyll content to $33 \%$ of the values found in plant grown a constant $28^{\circ} \mathrm{C}$. The comparable value for plants exposed to $16^{\circ} \mathrm{C}$ was $48 \%$.

\subsection{Thermostability of the chloroplast thylakiods of ts-mutants}

Figure 7 compares the thermostability of Hill reaction activity in three of the mutants and the wild type. The plants were grown in a growth chamber at $17 \pm 0.5^{\circ} \mathrm{C}$. At this growth temperature, chloroplast development was not inhibited in the ts-mutants. It can be seen from the figure that the photoreductive activities of the isolated chloroplasts of ts2, ts 4 and ts 46 were at least as thermostable as the activity of chloroplasts isolated from the wild type.

The heat sensitivity of chloroplasts can also be monitored by an increase in fluorescence of chlorophyll (14). This heat-induced rise in chlorophyll fluorescence can be measured in intact leaves and provides a means of ranking plants according to their heat sensitivity (14, 18).

Figure 8 shows fluorescence-heating curves for ts 57 and wild type. The curves were almost identical and similar measurements with ts 9 and ts 46 indicated that on the basis of the fluorescence changes, all three mutants were just as heat stable as the wild type.

\section{CONCLUSIONS}

The temperature sensitive reactions affected in the six investigated nuclear gene mutants are part of the early stages of plastid development. The phenotypes displayed by the mutants at 
growth temperatures spanning the range from permissive to restrictive temperatures is similar with respect to chlorophyll production, development of internal chloroplast structures and photochemical activities. Phenocopies of the mutants can be obtained by growing the wild type at temparatures above $32^{\circ} \mathrm{C}(5,17)$. Analogous phenotypes are obtained with oat, wheat and pea wild type seedlings grown under restrictive temperature conditions $(5,13)$. Since the etioplasts formed in the mutants at the permissive temperature can apparently develop into fully active chloroplasts at the restrictive temperature $\left(32^{\circ} \mathrm{C}\right)$, the six genes must code for six products either not needed in the assembly of the photosynthetic membranes or preformed in the dark. The six temperature sensitive mutants are potentially useful as markers for experiments with somatic hybridization involving barley. Pairs of mutants could be grown at the restrictive temperature and protoplasts produced from them for fusion. Regenerated fusion products of the two mutants could be selected by their capacity to green at a temperature non-permissive for the mutants in question.

\section{ACKNOWLEDGEMENTS}

Financial support by the Danish Atomic Energy Commission in connection with the screening, isolation and genetic characterization of the mutants is gratefully acknowledged. We would like to thank KIRSTEN KRISTIANSEN for her help in carrying out the crossing program with the mutants and ROBYN NOTT for technical assistance.

\section{REFERENCES}

1. ARnon, D. I.: Copper enzymes in isolated chloroplasts. Polyphenoloxidase in Beta vulgaris. Plant Physiol. 24, 1-15 (1949)

2. FARIS, J. A.: Cold chlorosis in sugar cane. Phytopathol 16,885-89! (1927)

3. Feierabend, J.: Temperature-sensitivity of chloroplast ribosome formation in higher plants. In "Genetics and Biogenesis of Chloroplasts and Mitochondria" Th. Bücher, W. Neupert, W. Sebald and S. Werner, Eds., pp 99-102. North Holland, Amsterdam (1976)
4. Feierabend, J., C. Berger \& A. Meyer: Spezifische Störung von Entwicklung und Enzymbildung der Plastiden höherer Pflanzen durch hohe Wachstumtemperaturen. Z. Naturforsch. 24b, 1641-1647 (1969)

5. Feierabend, J. \& M Mikus: Occurrence of a high temperature sensitivity of chloroplast ribosome formation in several higher plants. Plant Physiol. $59,863-867(1977)$

6. Feierabend, J. \& U. Schrader-ReichHardt: Biochemical differentiation of plastids and other organelles in rye leaves with a high temperatureinduced deficiency of plastid ribosomes. Planta $129,133-145$ (1976)

7. Henningsen, K. W., J. E. Boynton, D. von WetTSTEIN \& N, K. BoARdMaN: Nuclear genes controlling chloroplast development in barley. In: The Biochemistry of Gene Expression in Higher Organisms. J. K. Pollak and J. W. Lee, Eds., Australian \& New Zealand Book Comp. Sydney 1973, pp. 457-478

8. KARNOVSKY, M. J:: A formaldehyde-glutaraldehyde fixative of high osmolality for use in electron microscopy. J. Cell Biol. 27, 137A (1965)

9. MCWilliam, J. R. \& A. W. Naylor: Temperature and plant adaption. I. Interaction of temperature and light in the synthesis of chlorophyll in corn. Plant Physiol. 42, 1711-1715 (1967)

10. Melchers, G. \& G. IABIB: Somatic hybridization of plants by fusion of protoplasts. I. Selection of light resistant hybrids of "haploid" light sensitive varieties of tobacco. Molec. gen Genet. 135, 277-294 (1974)

11. Melchers, G., M. D. Sacristan \& A. A. HOLDER: Somatic hybrid plants of potato and tomato regenerated from fused protoplasts. Carlsberg Res. Commun. 43, 203-218 (1978)

12. Nolan, W. G. \& R. M. Smillie: Multi-temperature effects on Hill reaction activity of barley chloroplasts. Biochim. Biophys. Acta 440, 461-475 (1976)

13. SCHÄFERS, H. A. \& J. FEIERABEND: Ultrastructural differentiation of plastids and other organelles in rye leaves with a high-temperature-induced deficiency of plastid ribosomes. Cytobiologie 14, 75-90 (1976)

14. SChreiber, U. \& J. A. BerRY: Heat-induced changes of chlorophyll fluorescence in intact leaves correlated with damage of the photosynthetic apparatus. Planta (Berl.) 136, 233-238 (1977)

15. Slack, C. R., P. G. Roughan \& H. C. M. BASSETT: Selective inhibition of mesophyll chloroplast development in some C4-pathway species 
by low night temperature. Planta 118, 57-73 (1974)

16. Smillie, R. M.: Coloured components of chloroplast membranes as intrinsic membrane probes for monitoring the development of heat injury in intact tissue. Aust. J. Plant Physiol. 6, (1979) in press.

17. Smillie, R. M., C. Critchley, J. M. Bain \& R. NoTT: Effect of growth temperature on chloro- plast structure and activity in barley. Plant Physiol. 62, 191-196 (1978)

18. Smillie, R. M. \& R. NotT: Heat injury in leaves of alpine, temperate and tropical plants. Aust. J. Plant Physiol. 6, (1979) in press.

19. Wettstein, D. von \& K. KRISTIANSEN: Stock list for nuclear gene mutants affecting the chloroplast. Barley Genet. Newsl. 3, 113-117 (1973) 